\title{
Antibiotic-disc tests for rapid identification of non-sporing anaerobes
}

\author{
SUSAN PEACH ${ }^{1}$ \\ From the Department of Bacteriology, St Mary's Hospital Medical School, London
}

SYNOPSIS The sensitivity patterns to a number of antibiotic-impregnated discs of 126 strains of Gram-negative anaerobes and 36 strains of Gram-positive non-sporing anaerobes from various స sources have been examined. The sensitivity patterns shown by Bacteroides fragilis and Bacteroidesior melaninogenicus were useful for the rapid identification of these organisms. Consistent and useful $\mathbb{\infty}_{\infty}^{\infty}$ sensitivity patterns were not shown by the Gram-positive anaerobes.

Improvements in techniques for the isolation and cultivation of anaerobic organisms have led to an increase in the frequency of isolation of non-sporing anaerobes from clinical specimens (Moore, Cato, and Holdeman, 1969; McMinn and Crawford, 1970). These bacteria are also found in very large numbers in the human gastrointestinal tract (Sanborn, 1931; Haenel, 1970; Moore and Holdeman, 1974).

Identification of these organisms based on morphological and biochemical characteristics is tedious and time consuming; however, Finegold, Harada, and Miller (1967) have demonstrated the use of antibacterial susceptibility patterns as aids to the characterization of anaerobic Gram-negative bacilli, and Sutter and Finegold (1971) simplified and improved this method with the use of discs impregnated with high concentrations of antibiotics for rapid presumptive identification.

In this paper are presented the results obtained from the examination of a collection of non-sporing anaerobes using the special antibiotic-impregnated discs suggested by Sutter and Finegold (1971) as a guide to identification. It should be noted that the concentrations of antibiotics used for identification were in most cases too high for the results to be an indication of therapy.

\section{Materials and Methods}

Most of the bacteria in this study were isolated during a large survey of the faecal flora of people

${ }^{1}$ Present address: Bacterial Metabolism Laboratory, Rear of Colindale Hospital, Colindale Avenue, London NW9 5DX.

Received for publication 2 December 1974. consuming different diets in various parts of the $\vec{\omega}$ world (Peach, Fernandez, Johnson, and Drasar, 1974). The wound isolates came from routine wound swabs sent to the clinical laboratories of St Mary's Hospital, London (Peach and Hayek, 1974). Aō strain of Bacteroides fragilis (NCTC 9343) wasö obtained from the National Collection of Types Cultures, Colindale, London. Strains were identified $\overrightarrow{\vec{O}}$

\begin{tabular}{|c|c|c|}
\hline Species & Source & No. of Strains \\
\hline B. fragilis & $\begin{array}{l}\text { Faeces: } \\
\text { USA } \\
\text { India } \\
\text { Japan } \\
\text { Uganda } \\
\text { Scotland } \\
\text { Hong Kong } \\
\text { National Collection } \\
\text { Type Cultures } 9343 \\
\text { Wound infections }\end{array}$ & $\begin{array}{r}39 \\
11 \\
42 \\
6 \\
14 \\
3 \\
\\
1 \\
7\end{array}$ \\
\hline B. melaninogenicus & $\begin{array}{c}\text { Faeces: } \\
\text { USA }\end{array}$ & 3 \\
\hline Bifid. adolescentis & $\begin{array}{l}\text { Faeces: } \\
\text { USA } \\
\text { India } \\
\text { Japan } \\
\text { Uganda } \\
\text { Scotland } \\
\text { Hong Kong }\end{array}$ & $\begin{array}{r}11 \\
4 \\
1 \\
1 \\
1 \\
1\end{array}$ \\
\hline Bifid. bifidum & $\begin{array}{l}\text { Faeces: } \\
\text { USA } \\
\text { India } \\
\text { Japan } \\
\text { Scotland } \\
\text { Hong Kong }\end{array}$ & $\begin{array}{l}3 \\
1 \\
3 \\
3 \\
2\end{array}$ \\
\hline $\begin{array}{l}\text { Eubacterium } \\
\text { aerofaciens }\end{array}$ & $\begin{array}{c}\text { Faeces: } \\
\text { USA } \\
\text { India } \\
\text { Japan }\end{array}$ & $\begin{array}{l}3 \\
1 \\
1\end{array}$ \\
\hline
\end{tabular}


by the morphological and biochemical tests described by Holdeman and Moore (1972).

One hundred and twenty three strains of $B$. fragilis and three of $B$. melaninogenicus were examined (table I). Nineteen strains of Bifidobacterium adolescentis, 12 strains of Bifid. bifidum, and five strains of Eubacterium aerofaciens were also examined.

\section{CONDITIONS OF CULTURE}

Test strains were maintained by subculture in Robertson's cooked meat medium (Southern Group Laboratories Ltd). The culture medium for the sensitivity tests was Reinforced Clostridial Agar (Oxoid) containing 1\% glucose, $1 \%$ liver digest (Panmede, Paines and Byrne, Greenford, England), and $10 \%$ defibrinated horse blood. One or two drops of a three-day culture in Robertson's cooked meat medium were spread with a bent glass rod over the surface of the culture plates. Antibiotic discs, no more than four per plate, were then applied. The plates were incubated for three days at $37^{\circ} \mathrm{C}$ in a Baird and Tatlock anaerobe jar filled with a gas mixture containing $10 \% \mathrm{CO}_{2}$ and $90 \%$ hydrogen. Fresh Palladium D Catalyst (Englehard Industries, Cinderford, Glos.) was included in all the jars.

\section{ANTIBIOTIC DISCS}

Antibiotic discs were obtained from Mast Laboratories, Liverpool. The discs used were: colistin $10 \mu \mathrm{g}$, erythromycin $60 \mu \mathrm{g}$, kanamycin $1000 \mu \mathrm{g}$, neomycin $1000 \mu \mathrm{g}$, penicillin $2 \mathrm{u}(1 \cdot 2 \mu \mathrm{g})$, rifampicin $15 \mu \mathrm{g}$, and vancomycin $5 \mu \mathrm{g}$.

\section{Results}

Strains were designated 'resistant' to an antibiotic when there was no zone of inhibition around the disc. Strains of 'intermediate' resistance had zone diameters less than $10 \mathrm{~mm}$ and 'susceptible' strains had zone diameters greater than $10 \mathrm{~mm}$. The discs were $6 \mathrm{~mm}$ in diameter. There were no outstanding differences in the sensitivity patterns of strains of

\begin{tabular}{|c|c|c|}
\hline \multicolumn{2}{|c|}{ Sutter and Finegold (1971) (100 strains) } & This study (123 strains) \\
\hline Colistin & $\begin{array}{l}100 \mu \mathrm{g} \\
\mathrm{R} 100 \\
\mathrm{~S}- \\
\text { Intermediate - }\end{array}$ & $\begin{array}{r}94 \\
2.5 \\
3.5\end{array}$ \\
\hline Erythromycin & $\begin{array}{l}60 \mu \mathrm{g} \\
\quad \mathrm{R}- \\
\mathrm{S} 100 \\
\text { Intermediate - }\end{array}$ & $\begin{array}{r}1 \\
98 \\
1\end{array}$ \\
\hline Kanamycin & 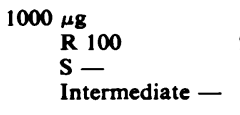 & $\begin{array}{r}96 \\
1 \\
3\end{array}$ \\
\hline Neomycin & $\begin{array}{l}1000 \mu \mathrm{g} \\
\text { R } 78 \\
\text { S } 20 \\
\text { Intermediate 2 }\end{array}$ & $\begin{array}{r}83 \\
15 \\
2\end{array}$ \\
\hline Penicillin & $\begin{array}{l}2 \text { units }(1 \cdot 2 \mu \mathrm{g}) \\
\text { R } 93 \\
\text { S } 7 \\
\text { Intermediate - }\end{array}$ & $\begin{array}{r}78 \\
19 \\
3\end{array}$ \\
\hline Rifampicin & $\begin{array}{l}15 \stackrel{\mu g}{ } \\
R 100 \\
S \rightarrow-1 \\
\text { Intermediate - }\end{array}$ & $\begin{array}{r}97.5 \\
2.5 \\
-\end{array}$ \\
\hline
\end{tabular}

Table II Susceptibility patterns of $B$. fragilis

Figures expressed as percentages; disc diameter $6 \mathrm{~mm} ; \mathbf{R}=$ no zone of inhibition; $S=$ diameter of inhibition zone $>10 \mathrm{~mm}$; Intermediate $=$ diameter of inhibition zone $<10 \mathrm{~mm}$.

the same species that had been isolated from faeces of varying geographical origins.

\section{BACTEROIDES FRAGILIS}

The antibiotic susceptibility patterns obtained for $B$. fragilis were comparable with those obtained by Sutter and Finegold (1971) and are shown in table II. All strains of $B$. fragilis tested were found to be resistant to a $5 \mu \mathrm{g}$ disc of vancomycin.

\section{BACTEROIDES MELANINOGENICUS}

Only three strains of $B$. melaninogenicus were tested and these differed in sensitivity to colistin and neomycin from 12 strains tested by Sutter and Finegold (1971). All three strains were resistant to a $5 \mu \mathrm{g}$ disc of vancomycin.

\begin{tabular}{|c|c|c|c|c|c|c|}
\hline \multirow[t]{2}{*}{ Antibiotic } & & \multicolumn{2}{|c|}{$\begin{array}{l}\text { Bifid. adolescentis } \\
\text { (19 strains) Percentage }\end{array}$} & \multicolumn{3}{|c|}{$\begin{array}{l}\text { Bifid. bifidum } \\
\text { (12 strains) } \quad \text { Percentage }\end{array}$} \\
\hline & & Resistant & Sensitive & Resistant & Sensitive & Intermediate \\
\hline $\begin{array}{l}\text { Colistin } \\
\text { Erythromycin } \\
\text { Kanamycin } \\
\text { Neomycin } \\
\text { Penicillin } \\
\text { Rifampicin }\end{array}$ & $\begin{array}{c}10 \mu \mathrm{g} \\
60 \mu \mathrm{g} \\
1000 \mu \mathrm{g} \\
1000 \mu \mathrm{g} \\
2 \mathrm{u}(1 \cdot 2 \mu \mathrm{g}) \\
15 \mu \mathrm{g}\end{array}$ & $\begin{array}{l}95 \\
32 \\
16 \\
10 \\
-\end{array}$ & $\begin{array}{r}5 \\
100 \\
68 \\
84 \\
90 \\
100\end{array}$ & $\begin{array}{l}92 \\
\overline{17} \\
17 \\
-\end{array}$ & $\begin{array}{r}8 \\
100 \\
75 \\
75 \\
100 \\
100\end{array}$ & $\begin{array}{l}- \\
8 \\
8 \\
-\end{array}$ \\
\hline
\end{tabular}

Table III Susceptibility patterns 
BIFIDOB A CTER I A

The antibiotic susceptibility patterns of 19 strains of Bifid. adolescentis and 12 strains of Bifid. bifidum were similar and are summarized in table III. These organisms were in general much less resistant to the test antibiotics than were the Gram-negative anaerobic bacteria. In addition, all strains tested were sensitive to a $5 \mu \mathrm{g}$ disc of vancomycin.

EUBA CTERIA

Five strains of Eubacterium aerofaciens were tested and no clear pattern of antibiotic sensitivity emerged (table IV). There was a marked variation between strains. However, all strains were sensitive to the $5 \mu \mathrm{g}$ disc of vancomycin.

\begin{tabular}{|c|c|c|c|c|c|c|}
\hline \multirow[t]{2}{*}{ Strain } & & \multicolumn{5}{|c|}{ Individual Sensitivities } \\
\hline & & $A$ & $B$ & $C$ & $D$ & $E$ \\
\hline $\begin{array}{l}\text { Colistin } \\
\text { Erythromycin } \\
\text { Kanamycin } \\
\text { Neomycin } \\
\text { Penicillin } \\
\text { Rifampicin }\end{array}$ & $\begin{aligned} 100 \mu \mathrm{g} \\
60 \mu \mathrm{g} \\
1000 \mu \mathrm{g} \\
1000 \mu \mathrm{g} \\
2 \mathrm{u}(1 \cdot 2 \mu \mathrm{g}) \\
15 \mu \mathrm{g}\end{aligned}$ & $\begin{array}{l}\mathbf{R} \\
\mathbf{S} \\
\mathbf{S} \\
\mathbf{S} \\
\mathbf{R} \\
\mathbf{S}\end{array}$ & $\begin{array}{l}S \\
S \\
S \\
S \\
S \\
S\end{array}$ & $\begin{array}{l}\mathbf{R} \\
\mathbf{S} \\
\mathbf{S} \\
\mathrm{S} \\
\mathbf{S} \\
\mathrm{S}\end{array}$ & $\begin{array}{l}\mathbf{S} \\
\mathbf{R} \\
\mathbf{S} \\
\mathbf{S} \\
\mathbf{S} \\
\mathbf{R}\end{array}$ & $\begin{array}{l}\mathbf{R} \\
\mathbf{S} \\
\mathbf{R} \\
\mathbf{R} \\
\mathbf{S} \\
\mathbf{S}\end{array}$ \\
\hline
\end{tabular}

Table IV Antibiotic susceptibility patterns of five strains of Eubacterium aerofaciens

$\mathbf{R}=$ no zone of inhibition $; S=$ diameter of inhibition zone $>10 \mathrm{~mm}$; Intermediate $=$ diameter of inhibition zone $<10 \mathrm{~mm}$.

\section{Discussion}

The need for a rapid method for the presumptive identification of non-sporing anaerobic bacteria, especially those isolated from clinical material, is becoming increasingly important. Gram-negative anaerobic bacteria, in particular $B$. fragilis and $B$. melaninogenicus, are frequently isolated from clinical specimens (Stokes, 1958; Moore et al, 1969) and a means of identification during primary isolation would be advantageous.

The antibacterial susceptibility patterns of strains of $B$. fragilis tested during this study were similar to those obtained by Sutter and Finegold (1971). However, fewer isolates were found to be resistant to a disc containing 2 units $(1 \cdot 2 \mu \mathrm{g})$ of penicillin. Strains used in the present study had been recently isolated from the intestine. Those tested by Sutter and Finegold included stock strains and clinical isolates. Fievez (1963) noted that the Gram-negative anaerobe Sphaerophorus necrophorus was more sensitive to penicillin on primary isolation than after several subcultures. It may be that a similar phenomenon occurs with Bacteroides. Most of the clinical isolates tested in the present study were resistant to 2 units of penicillin.
Only three strains of $B$. melaninogenicus were available for study and their sensitivity to colistin: and neomycin differed from that of the 12 strainst studied by Sutter and Finegold. The most striking difference was sensitivity to neomycin. All the strains of B. melaninogenicus studied by Sutter anf Finegold were sensitive to $100 \mu \mathrm{g}$ neomycin; i⿱ contrast, the three strains in the present study wer\& resistant to this concentration. Garrod (1955), in a plate dilution study, found $B$. melaninogenicus was. resistant to streptomycin. In this study and in the study by Sutter and Finegold B. melaninogenicus wa? found to be resistant to kanamycin. Martin? Gardner, and Washington (1972), using an agatio dilution technique, found $B$. melaninogenicus to bo sensitive to rifampicin and erythromycin; mosis strains were sensitive to penicillin $G$ and resistant $t 8^{\circ}$ kanamycin. These trends are also shown in the dis 8 sensitivity tests of Sutter and Finegold and in the present investigation.

Susceptibility to a $5 \mu \mathrm{g}$ disc of vancomycin as recommended by Sutter, Attebery, Rosenblatto Bricknell, and Finegold (1972) proved to be useful 'back-up' for a Gram-reaction. All the Gramo negative anaerobes in this study were resistant to such a disc. All the Gram-positive organisms were sensitive.

There is no solid evidence for pathogenicity of the Gram-positive non-sporing anaerobic bacteria, a though they are often isolated from clinical materia? in mixed culture with facultative organisms or with Gram-negative anaerobes (Smith and Holdemare 1968; Moore et al, 1969). However, these bacteria also form a major part of the intestinal microflora of man (Peach et al, 1974). There were few diffe ences in antibiotic sensitivity between the two species. of bifidobacteria tested in the present study. Bot Bifid. adolescentis and Bifid. bifidum were sensitive to the discs of penicillin and erythromycin. Mof strains of Bifid. adolescentis were resistant to the kanamycin disc than were the strains of Bifi bifidum. These results are similar to those of a plate dilution sensitivity test reported by Miller and Finegold (1967). Miller and Finegold found thä Bifid. adolescentis was more sensitive to neomycto than Bifid. bifidum. Lavergne, Burdin, Schmitt, anet Manciaux (1959) found the sensitivity of Bifid. bifidum to erythromycin and neomycin to be similă to that found by Miller and Finegold.

Courtieu, Monnier, de Lajudie, and Guillermer (1960) reported a single strain of bifidobacteria to sensitive to colistin. However, Miller and Finegote (1967) found bifidobacteria to be resistant to te related antibiotic polymyxin $B$ and in the presegt study most strains of Bifid. adolescentis and Bifid. bifidum were resistant to colistin. 
Eubacterium aerofaciens was more sensitive to the test antibiotics than were the bifidobacteria. Martin et al (1972), using an agar dilution technique, found that, in general, bifidobacteria (unidentified species) were more sensitive than eubacteria to erythromycin, penicillin, and rifampicin. In the present study, using antibiotic discs, eubacteria and bifidobacteria showed similar sensitivity patterns to these antibiotics.

The results of the present study indicate that antibiotic disc susceptibility patterns as proposed by Sutter and Finegold (1971) provide a reliable method for the rapid presumptive identification of $B$. fragilis. Identification of $B$. melaninogenicus can also be achieved provided the system is backed up by other simple tests, such as those recommended by Sutter and Finegold (1971). This method would be useful for the initial presumptive identification of these two species of anaerobe, particularly those isolated from clinical specimens. However, identification on an initial isolation plate is not achieved and the time taken to isolate and purify a culture is not eliminated.

The sensitivity of an isolate to the high concentrations of antibiotics used in this study would give no indication of the sensitivity of this strain to concentrations of antibiotics obtainable in vivo. In this light a separate sensitivity plate would have to be prepared.

Using the same antibiotics recommended for the identification of Gram-negative anaerobes, no distinguishing pattern of antibiotic sensitivity suitable for identification of Gram-positive anaerobes emerged. It may be that different antibiotics, or different concentrations of antibiotic, are needed to provide a similar rapid preliminary identification of these organisms, and an investigation in this direction is desirable.

As with all tests for antibiotic susceptibility the possibility of acquired resistance, even to the high concentrations of antibiotics used in this study, should be remembered in interpretations of results.

This study was part of a larger project generously supported by the Cancer Research Campaign.

\section{References}

Courtieu, A. L., Monnier, J. J., de Lajudie, P., and
Guillermet, F. N. (1960). Spectre antibactérien de la colistine vis-à-vis de 1200 souches. Ann. Inst. Pasteur, 100, Suppl pp. 14-31.

Fievez, L. (1963). Étude Comparée des Souches de Sphaerophorus necrophorus Isolées chez l'Homme et chez l'Animal. Presses Académiques Européennes, Brussels.

Finegold, S. M., Harada, N. E., and Miller, L. G. (1967). Antibiotic susceptibility patterns as aids in classification and characterization of Gram-negative anaerobic bacilli. J. Bact., 94, 1443-1450.

Garrod, L. P. (1955). Sensitivity of four species of Bacteroides to antibiotics. Brit. med. J., 2, 1529-1531.

Haenel, H. (1970). Human normal and abnormal gastrointestinal flora. Amer. J. clin. Nutr., 23, 1433-1439.

Holdeman, L. .V. and Moore, W. E. C. (1972). (Editors) The Anaerobe Laboratory Manual. Virginia Polytechnic Institute and State University, Blacksburg, Virginia.

Lavergne, E. de., Burdin, J. C., Schmitt, J., and Manciaux, M. (1959). Sensibilité de Bifidibacterium bifidum à onze antibiotiques. Ann. Inst. Pasteur, 97, 104-107.

McMinn, M. T. and Crawford, J. J. (1970). Recovery of anaerobic microorganisms from clinical specimens in prereduced media versus recovery by routine clinical laboratory methods. Appl. Microbiol., 19, 207-213.

Martin, W. J., Gardner, M., and Washington, J. A., II (1972). In vitro antimicrobial susceptibility of anaerobic bacteria isolated from clinical specimens. Antimicrob. Agents Chemother., 1, 148-158.

Miller, .L. G. and Finegold, S. M. (1967). Antibacterial sensitivity of Bifidobacterium (Lactobacillus bifidus). J. Bact., 93, 125-130.

Moore, W. E. C., Cato, E. P., and Holdeman, L. V. (1969) Anaerobic bacteria of the gastrointestinal flora and their occurrence in clinical infections. $J$. infect. Dis., 119, 641649.

Moore, W. E. C. and Holdeman, L. V. (1974). Human fecal flora: the normal flora of 20 Japanese-Hawaiians. Appl. Microbiol., 27, 961-979.

Peach, S., Fernandez, F., Johnson, K., and Drasar, B. S. (1974). The non-sporing anaerobic bacteria in human faeces. J. med. Microbiol., 7, 213-221.

Peach, S. and Hayek, L. (1974). The isolation of anaerobic bacteria from wound swabs. J. clin. Path., 27, 578-582.

Sanborn, A. G. (1931). The fecal flora of adults, with particular attention to individual differences and their relationship to the effects of various diets. I. Individual differences on normal diet. J. infect. Dis., 48, 541-569.

Smith, L. D. S. and Holdeman, L. V. (1968). The Pathogenic Anaerobic Bacteria. Thomas, Springfield, Illinois.

Stokes, E. J. (1958). Anaerobes in routine diagnostic cultures. Lancet, 1, 668-670.

Sutter, V. L., Attebery, H. R., Rosenblatt, J. E., Bricknell, K. S., and Finegold, S. M. (1972). Anaerobic Bacteriology Manual. University of California, Los Angeles.

Sutter, V. L. and Finegold, S. M. (1971). Antibiotic disc susceptibility tests for rapid presumptive identification of Gram-negative anaerobic bacilli. Appl. Microbiol., 21, 13-20. 
matters but the bulk of the volume is devoted to correlations between clinical aspects and histology.

The section by Sherman dealing with differentiation during embryogenesis evokes some important and fundamental issues which sit somewhat uneasily in this largely practical manual. Franzen summarizes his considerable experience with aspiration biopsy, a technique which is perhaps worthy of more widespread adoption. There is an interesting presentation by Casarett and his colleagues describing a quantitative histological approach to radiosensitivity and response which does attempt to get to grips with the problem of providing an objective histological measure of therapeutic response.

In the clinical section there are two chapters on the prognostic significance of histological grade in breast cancer. The first by Hutter discusses the general aspects of pathology in relation to prognosis, and the second by Bloom describes in some detail his well-known earlier studies on tumour grading in breast tumours in relation to patient survival. The clinical section, which also deals with histology in relation to lung, bladder, and prostatic cancer, describes the current position in Hodgkin's disease where it is of considerable interest that the prognostic significance of the histological sub-type appears to be changing so that the distinction between nodular sclerosis and mixed cellularity may be less important than was previously thought. This emphasizes an important consideration in the identification of prognostically significant features in any human malignancy, namely, that with changing investigative and therapeutic attitudes features which once significantly determined prognosis may no longer do so.

With the reservations expressed above, this latest edition of the excellent series of Frontiers of Radiation Therapy and Oncology maintains the high standard set by the previous volumes and will be of interest and value to both pathologists and clinicians working in the cancer field.

M. J. PECKHAM

Laboratory Instrumentation. Edited by R. Hicks, J. R. Schenken, and Mary Ann Steinrauf. (Pp. 237; 135 figs; \$9.95.) London, Maryland, New York, San Francisco: Harper and Row. 1974.

The authors' intention is to attempt to bridge the gap between the larger textbooks on theory and the manufacturers' instrument manuals. It was developed for use as an instructional course manual by the faculty of medical technology of a United States university.

The book is divided into 18 sections; the first deals with the elementary principles of electricity in 20 pages. Other subjects covered are spectrophotometry, pH + blood gas analysis, osmometry, refractometry, scintillation counting, gas-liquid chromatography, the Coulter A, B, Fn + S, the Technicon Autoanalyzer, balances, diluters, and centrifuges.

Each section starts with a glossary of definitions which is followed by an explanation of instrument components and how they are incorporated in a typical instrument. Each chapter includes its own set of refrences.

No attempt is made to compare different makes of instrument. The preface states that mention of a specific instrument is not an endorsement of the instrument nor is failure to mention a particular instrument an indication of inferiority or unacceptability.

The authors have of necessity had to be selective but there are some important omissions. No mention is made of rate reaction analysers, discrete analysers such as the Vickers multi and dual channel machines or specific glucose analysers, and only four pages are devoted to fluorimetry, whereas refractometry is allocated 14 pages. A glossary of abbreviations is provided at the beginning of the book, which is useful except that the abbreviation for aspartate amino transference is given as S.G.O.T!

A section giving some guidance on how to check the validity of makers' claims of performance would be useful.

Despite these criticisms, the book is well produced, easy to use, and well illustrated with simple line drawings.

I think this book should be of value to those studying for $\mathrm{HNC}$ and the Advanced Final of the IMLT, the MCB, MRC Path in clinical chemistry, and wherever a basic knowledge of the principles of operation of instruments used in the medical laboratory is required.

JOYCE L. BELL

\section{Errata}

In Antibiotic-disc tests for rapid identification of non-sporing anaerobes by Susan Peach (J. clin. Path., 1975, 28, 388-391) the results shown in table II regarding the susceptibility of $B$. fragilis to rifampicin have been printed the wrong way round. Instead of:

Rifampicin $15 \mu \mathrm{g}$

$$
\text { R } 100
$$

the table should read:

Rifampicin $15 \mu \mathrm{g}$

$\begin{array}{ll}\mathrm{R}- & 2 \cdot 5 \\ \mathrm{~S} 100 & 97 \cdot 5 \\ \text { Intermediate } & -\end{array}$

In An experimental comparison of Thiol broth with Brewer's thioglycollate for anaerobic blood cultures by D. C. Shanson and M. Barnicoat (J. clin. Path., 1975, 28, 407-409) there was an error in the table. B. melaninogenicus strain NCTC 9337 should have appeared with a 0 in the $24 \mathrm{hr}$ column, with Southern Group Brewer's medium, instead of the + shown. 